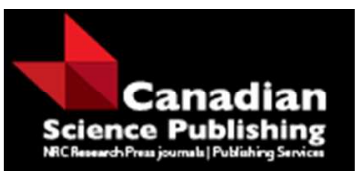

Canadian Journal of Forest Research Revue canadienne de recherche forestière

\title{
Predicting White Spruce Cone Crops in the Boreal Forests of the Southern and Central Yukon
}

\begin{tabular}{|r|l|}
\hline Journal: & Canadian Journal of Forest Research \\
\hline Manuscript ID & cjfr-2016-0180.R1 \\
\hline Danuscript Type: & Article \\
\hline Complete List of Authors: & $\begin{array}{l}\text { Krebs, Charles; Department of Zoology } \\
\text { ODonoghue, Mark; Department of the Environment } \\
\text { Taylor, Shawn; Environment Yukon, Fish and Wildlife Branch } \\
\text { Kenney, Alice; University of British Columbia, Department of Zoology } \\
\text { Hofer, Elizabeth; University of British Columbia, Department of Zoology } \\
\text { Boutin, Stan; University of Alberta, Department of Biological Sciences }\end{array}$ \\
\hline Keyword: & $\begin{array}{l}\text { white spruce cone production, Yukon, Picea glauca, delta-t model, mast } \\
\text { seeding }\end{array}$ \\
\hline \multicolumn{2}{|c}{} \\
\hline
\end{tabular}


1 Predicting White Spruce Cone Crops in the Boreal Forests of the Southern and Central Yukon

3 C.J. Krebs ${ }^{1}$, M. O’Donoghue ${ }^{2}$, Shawn Taylor $^{3}$, A.J. Kenney ${ }^{1}$, E.J. Hofer ${ }^{1}$, and S. Boutin ${ }^{4}$

$4{ }^{1}$ Department of Zoology, University of British Columbia, Vancouver, B.C., V6T 1Z4

5 krebs@zoology.ubc.ca, kenney@zoology.ubc.ca, elizabethj.hofer@gmail.com

$6 \quad{ }^{2}$ Environment Yukon, Fish and Wildlife Branch, P.O. Box 310, Mayo, Yukon Y0B 1M0

$7 \quad$ Mark.ODonoghue@gov.yk.ca

$8 \quad{ }^{3}$ Environment Yukon Fish and Wildlife Branch, Box 5429, Haines Junction Y0B 1L0

9 Shawn.Taylor@gov.yk.ca

$10{ }^{4}$ Department of Biological Sciences, University of Alberta, Edmonton, Alberta, T6G 2E9

11 sboutin@ualberta.ca

12 Corresponding author: Charles Krebs

13 Phone: 604-822-3957

14 Fax: (604) 822-2416

15 *Email: krebs@,zoology.ubc.ca

16 Running Head: Predicting white spruce cone crops 


\section{Abstract}

19 White spruce cone crops were measured at five regional centers in the southern and central

20 Yukon for 30 years at one site from 1986 to 2015 and at four other sites from 9-11 years to select

21 the best climatic model that use cues from growing season temperature and rainfall to predict the

22 size of cone crops. We evaluated six climate models that use summer temperature and rainfall of

23 years $t-1$, and $t-2$ to predict cone crops in year $t$. July temperatures provided the best predictors of

24 white spruce cone crops and no rainfall variable was related to the size of cone crops. We

25 explored three variants of July temperatures: mean temperature, degree-days $>5^{\circ} \mathrm{C}$, and

26 maximum temperatures. For each of these we used the $\Delta \mathrm{T}$ model that uses the difference in the

27 July temperature measures of year $t-1$ and $t-2$. We compared the resulting 6 models with AIC $\mathrm{c}_{\mathrm{c}}$ to

28 determine their relative predictive performance. The best model combined $\Delta \mathrm{T}$ measures of

29 degree-days $>5^{\circ} \mathrm{C}$ and the four highest daily maximum July temperatures with $R^{2}=0.65$. By

30 comparison the $\Delta \mathrm{T}$ model involving only mean July temperatures was less successful $\left(R^{2}=\right.$

31 0.49). There was good regional synchrony $\left(r_{p}=0.7\right.$ to 0.8$)$ in high cone crops over the southern

32 and central Yukon during 1986 to 2015.

33 Keywords: white spruce cone production, Yukon, climate, Picea glauca, delta-t model, mast

34 seeding 


\section{Introduction}

Cone crops of white spruce (Picea glauca (Moench) Voss) in the boreal forest region vary dramatically from year to year. A combination of climatic events are usually put forward to explain these variations in plant production (Juday et al. 2003; Messaoud et al. 2007; Allen et al. 2014, Pearse et al. 2016). In 2012 we produced a quantitative model for the prediction of white spruce cone crops in the Yukon from climatic factors one and two years prior to the crop (Krebs et al. 2012). After our analysis, a new model, the $\Delta \mathrm{T}$ model, for cone crops was proposed by Kelly et al. (2013). This model is based solely on temperature in the growing season of the previous 2 years, and is thus a conceptually simple model suggesting the cues for the response of masting trees to temperature variations.

The new $\Delta \mathrm{T}$ model is particularly attractive as an alternative model because of its simplicity, involving only summer temperatures, and because as Kelly et al. (2013) show the $\Delta \mathrm{T}$ model fits a variety of masting records from many plant species and thus achieves a level of generality often lacking in climatic models of biological events. Climatic models are particularly difficult to construct because of the plethora of variables possible, so that development of models can too often turn into a fishing expedition.

We began measuring white spruce cone production in the Kluane region in 1986 because of the ecological implications of highly variable seed crops for seed-eating mammals and birds. We have added data here from the Yukon Community Ecological Monitoring Program (CEMP) for sites at Faro (2007-2015), Mayo, Whitehorse, and Watson Lake (all 2005-2015). The utility of a model of masting is that natural resource managers and government seed collection agencies can use it to anticipate years of high and low seed production, particularly if the model predictions can be generalized over large spatial areas. 
This paper reports on the statistical associations between climatic measurements and

60 white spruce cone production for all these CEMP regions in the southern and central Yukon.

61 In a broader context we wish to determine if temperature, rainfall, or both are the best predictors

62 of the size of future white spruce cone crops and to estimate which monthly variables are the best

63 predictors. We focus on $\Delta$-models measuring the difference in any particular climatic variable

64 one year before and that measurement two years before the observed cone crop. We emphasize

65 here that we view growing season temperature and rainfall as possible cues to subsequent cone

66 production and we do not know for this system how temperature and rainfall might relate to the

67 proximate physiological drivers that have a direct, mechanistic relationship with cone

68 production.

69 Methods

70 The Study Areas

71 The study regions are all in the southern and central Yukon and all contain tree

72 communities with abundant white spruce. Figure 1 shows the locations of the 5 regions and

73 Table 1 gives the average summer temperature and rainfall for each region for the last 30 years.

74 The climate in all regions is continental, and as a consequence tree growth and forest succession

75 are slow. The effects of climate change in these regions in the last 50 years are significant but not

76 large (Conway and Danby 2014). From 1980-2014 the change of July summer temperature at the

77 Haines Junction weather station has been $0.021^{\circ} \mathrm{C}$ increase per year, a slight but significant

78 change $(p=0.04)$. Summer rainfall trends for the June and July time period are also non-

79 significant $(p=0.53)$. The 5 regions are spread across about $390 \mathrm{~km}$ north-south and $550 \mathrm{~km}$

80 east-west, covering a boreal forest area of about $200,000 \mathrm{~km}^{2}$.

$81<$ TABLE 1 ABOUT HERE $>$ 


\section{Weather Data}

Weather data were obtained from Environment Canada for weather stations at each of the

845 regions. The Kluane Lake study areas are located between the Haines Junction and Burwash

85 Airport weather stations. For these 5 regional areas, Mayo is the warmest in summer along with

86 Watson Lake, and Kluane the coldest (Burwash and Haines Junction area). Rainfall is highly

87 variable with Watson Lake the wettest and Whitehorse the driest. We found that either Burwash

88 Airport data or Haines Junction data could be used for analysis of white spruce cone production

89 at Kluane Lake. We chose the Haines Junction weather data because they had less missing data

90 and are slightly closer to most of our Kluane study sites.

\section{Cone Crop Estimation}

92 We measured white spruce cone crops of individual tagged trees at all locations with the

93 same methods. Only trees $>10 \mathrm{~cm}$ DBH were used. New cones were counted in the top $3 \mathrm{~m}$ from

94 one side of each tree by the use of binoculars. If more than 100 cones were present, a photograph

95 was taken and counted later on a computer. These index counts refer to only one side of the tree,

96 and we converted these to whole tree cone counts with the equation developed by LaMontagne et

97 al. (2005) who sampled 60 whole trees destructively to develop an equation to transform index

98 counts to total tree counts of cones. Not all regions were counted in all years. Table 2 gives a

99 summary of the number of trees counted at each region each year. When we discuss data on cone

100 crops in this paper we are referring to the total number of cones per tree obtained from our index

101 counts by means of the LaMontagne et al. (2005) transformation.

102 At Kluane Lake individual spruce trees to be counted were located systematically at $42 \mathrm{~m}$

103 intervals on checkerboard 36 ha snowshoe hare live trapping grids (Krebs et al. 2001) so that for 104 most grid sites 86 trees were counted. For the other 4 regions we used 2 (or 4 ) parallel lines 100 
$105 \mathrm{~m}$ apart, with 50 (or 25) stations in each line, spaced at $15 \mathrm{~m}$ intervals, for a minimum sample

106 size of about 100 trees per region (Table 2$)$. All trees were tagged. Some trees $(<1 \%)$ died in a

107 given year or were broken off by wind and a new tree had to be located. Data were pooled at all

108 sampling sites within each of the 5 regions. The mean cone count per tree for each year averaged

109 over all sampling sites within each of the 5 regions was the dependent variable used in statistical

110 analyses. Over all the years a total of 71 region-years of data were available with the longest time

111 series being 30 years at Kluane Lake.

$112<$ TABLE 2 ABOUT HERE $>$

113 Spruce cones were counted in late July or early August while they were still green and before

114 red squirrels (Tamiasciurus hudsonius) began to harvest them in late August (early boreal

115 autumn, Fletcher et al. 2013).

\section{Weather Variables}

117 We used standard weather data from nearby meteorological stations (Table 1) to estimate

118 for each potential cone crop year for each region the mean July temperature, and used that as the

$119 \Delta \mathrm{T}$ measure suggested by Kelly et al. (2013), which is one measure of the difference in warmth

120 between the two previous growing seasons. We estimated $\Delta \mathrm{T}$ from mean daily temperature from

121 mid-June to mid-August and for July only. There was a very high correlation between these

122 measures from June 16 to August 15 and the same measures in July $(r>0.97)$ so we used the

123 simplest July-only measures of the temperature of the growing season. $\Delta \mathrm{T}$ is defined here as:

$124 \Delta T=$ mean July temperature (year $t-1)$ - mean July temperature (year $t-2)$

125 Growing-degree-days might provide a more precise measure of summer warmth for spruce trees.

126 For each region we calculated growing-degree days for each July from daily mean temperatures 
127 by subtracting 5 from each day in which the mean temperature was above $5^{\circ} \mathrm{C}$ and then summing

128 these for July. We then calculated $\Delta$ degree-days by the equation:

growing-degree days for day $\mathrm{X}=$ mean daily temperature for day $\mathrm{X}-5$

$(=0$ if mean daily temperature was below $5 \mathrm{C})$

$\Delta$ growing-degree days $=$ total growing-degree days $($ July $t-1)$

$$
\text { - total growing-degree days(July } t-2)
$$

131 We used degree-days above $5^{\circ} \mathrm{C}$ but would get the exact same results with degree-days above

$132 \quad 0^{\circ} \mathrm{C}$ since virtually all July temperatures are above $5^{\circ} \mathrm{C}$.

133 There are many other measures of temperature that could be used, and we added one more,

134 the mean of the 4 highest daily temperatures in July, to determine if cone crops were influenced

135 by extreme values of summer temperature rather than mean values.

136 In addition to temperature data we looked for correlations with rainfall in each of the summer

137 growing season months from May to August in year $t$-1 and $t-2$. We checked all these weather

138 variables from year $t$-3 and found no significant correlations so we have gone back only to year

$139 t-2$ for weather variables.

140 Statistical Analysis

141 Statistical analysis is limited to data from the 30-year period 1986 to 2015. All statistical

142 analyses were done in NCSS 10 (Number Crunching Statistical System, Kay, Utah,

143 www.ncss.com ). Multiple regressions for all the models were computed by the use of robust

144 regression following Huber's Method $(\mathrm{C}=1.345)$ to reduce the impact of outliers in the data, as

145 suggested by Kutner et al. (2005) and Huber and Ronchettti (2009). Confidence limits for all

146 estimates were estimated by bootstrapping 10,000 samples. Synchrony among areas was

147 quantified using methods suggested by Koenig et al. (2003). All cone count and temperature data

148 are given in the Supplementary Material Table S1. 


\section{Results}

\section{Testing Temperature and Rainfall Variables}

We carried out an extensive exploratory data analysis on all monthly summer (May to

152 September) temperature and rainfall variables from the two years prior to cone production. We

153 found no monthly rainfall variables that were correlated with spruce cone counts either as

154 individual months or as the analogue to the delta-t method, using rainfall instead of temperature.

155 The only significant correlations were obtained from midsummer temperatures of both of the two

156 years before the cone crop. We calculated five possible measures of midsummer temperatures for

157 July: mean temperature, total degree days $>5^{\circ} \mathrm{C}$, total degree-days $>10^{\circ} \mathrm{C}$, average of the 4

158 maximum temperatures, average of the 8 maximum temperatures. We deleted total degree-days

$159>10^{\circ} \mathrm{C}$ and the average of 8 maximum temperatures from the analysis because they were poorly

160 correlated with cone crops. We explored the best measure for cone crops and found that the

161 square root transformation was the preferred transformation for the assumption of normality in

162 the cone data (Shapiro-Wilk W $=0.976, p=0.22$ ). Table 3 gives the correlations between the

163 cone counts and the temperature variables used in our analysis.

$164 \quad<$ TABLE 3 ABOUT HERE >

165 We calculated robust multiple regressions for each combination of temperature variables

166 possible with the results given in Table 4. The best model (eq. 4) for predicting cone crops

167 included two July weather variables expressed as $\Delta$ year $(\mathrm{t}-1)$ - year (t-2): degree-days $>5^{\circ} \mathrm{C}$ and

168 the average of 4 maximum July temperatures. This regression is given by:

$$
\begin{gathered}
\sqrt{\text { total cones per tree }}=12.5798+0.0812(\Delta \text { degree-days July }) \\
+2.1408(\Delta 4 \text { max temperatures July })
\end{gathered}
$$

170 The second best model (eq. 5) included 3 July weather variables all in $\Delta$ format: degree days

$171>5^{\circ} \mathrm{C}$, mean temperature, and the average of 4 highest temperatures in July. The second best 
172 model showed only slightly poorer fit than the best model (Table 4) with an $\mathrm{AIC}_{\mathrm{c}} 2.08$ likelihood

173 units below the best model, and an evidence ratio of 2.83 .

$$
\begin{gathered}
\sqrt{\text { total cones per tree }}=12.6095+0.06197(\Delta \text { degree-days July }) \\
+2.0800(\Delta 4 \text { max temperatures July })+0.7071(\Delta T \text { July })
\end{gathered}
$$

175 The third best model (eq. 6) was 2.46 likelihood units below the best model, with an evidence

176 ratio of 3.42.

$$
\begin{aligned}
\sqrt{\text { total cones per tree }}= & 12.5056+2.0648(\Delta 4 \max \text { temperatures July }) \\
& +2.4616(\Delta T \text { July })
\end{aligned}
$$

178 The fourth model with a low evidence ratio was a model using the mean July temperature of year

$179(\mathrm{t}-1)$, the mean July temperature of year $(\mathrm{t}-2)$ and the $\Delta \mathrm{T}$ of the mean of the 4 highest

180 temperatures in July for the previous 2 years.

$$
\begin{aligned}
\sqrt{\text { total cones per tree }} & =23.2543+1.9532(\Delta 4 \max \text { temperatures July) } \\
& +2.2732(\text { mean July temp. }(\mathrm{t}-1))-3.0210(\text { mean July temp. }(\mathrm{t}-2))
\end{aligned}
$$

182 The fifth model was the Krebs et al. (2012) model, and the sixth model (eq. 8) was the simple $\Delta$

183 T model on July mean temperatures had much less support.

$$
\sqrt{\text { total cones per tree }}=0.1024+5.1310(\Delta T \text { July })
$$

185 The weather variable with the highest standardized coefficient for both the first and second

186 models was the $\Delta \mathrm{T}$ of the mean of the 4 highest temperatures in July (0.53), compared with the

$187 \Delta \mathrm{T}$ of degree-days in July (0.33). One additional reason for not preferring the second (eq. 5) and

188 third (eq. 6) models (in addition to the $\mathrm{AIC}_{\mathrm{c}}$ analysis) is that they both fail the normality

189 assumption of multiple regression as measured by the Shapiro-Wilk test.

Figure 2 shows the observed cone counts and the predicted counts from the best statistical

191 model (eq. 4) listed in Table 4. A curious but unexplained aspect of this graph is that the

192 predicted counts tend to be too large when small cone crops occur but too small when the major 
193 masting years occur with very large cone crops. Simple one-variable scatter plots of the two most

194 important variables in the multiple regression are shown as $\Delta \mathrm{T}$ variables in Figure 3 (4

195 maximum July temperatures) and Figure 4 (degree days $>5^{\circ} \mathrm{C}$ in July). The most interesting

196 aspect of Figure 3 is that there appears to be a threshold in $\Delta$ July maximum temperatures around

$197-2^{\circ} \mathrm{C}$ below which there is virtually no cone production. The correlation shown here is not

198 improved by fitting a threshold model and truncating the observed data at $-2^{\circ} \mathrm{C}$

199 Figure 2 suggests visually that all the data from the 5 regions fit a single line. We tested

200 this hypothesis with an analysis of covariance (NCSS 10) and accepted a common slope

201 assumption $\left(\mathrm{F}_{4,47}=1.07, p=0.38, n=66\right)$ and no significant difference among adjusted means

$202\left(\mathrm{~F}_{4,60}=1.13, p=0.35\right)$. The covariance test is weakened somewhat by sample sizes which are much

203 higher for Kluane Lake $(n=30)$ than for the other 4 regions ( $n$ from 9 to 11). But from the

204 present data we have no statistical indication that we can reject the assumption that one

205 regression fits all 5 regions of the Yukon.

206 Discussion

207 Plants that seed irregularly store energy for one or more years and then use that energy to

208 flower and fruit (Koenig and Knops 2005, Vander Kloet and Cabilio 1996, Pearse et al. 2014).

209 For white spruce at these 5 Yukon regions summer temperature in the two years prior to the cone

210 crop seems to be a cue that can be used to estimate the predicted size of the cone crop before it

211 occurs. A similar result highlighting temperature rather than rainfall as the best predictor was

212 reported by Norton and Kelly (1988). We do not know if temperature is the proximate driver for

213 the cone crop because we do not know the mechanism by which temperature acts in this

214 ecosystem (see discussion in Pearse et al. 2014). For Yukon white spruce we checked to see if

215 there was any evidence of inherent cyclic rhythms in the cone crops (spectral analysis in NCSS 
$\underline{\text { Krebs et al. }}$

Page 11

216 10), and there is no regular cycle visible in the data we have covering 30 years at Kluane Lake.

217 There is also no inherent cyclic rhythm in July temperatures for the last 30 years at Haines

218 Junction (spectral analysis).

219 There are many variables that could affect the success of a masting event, from failure of

220 pollination, insect attacks, snowstorms, or other singular bad weather events. The ability of

221 simple statistical models to capture the main factors quantitatively predicting successful masting

222 events has been limited and this could be because the time series of data on masting is shorter

223 than needed for a good statistical model or that the best model has not yet been articulated.

224 Two important points are shown by our analyses. The best weather model in our analysis

225 was a robust predictor for all regions and achieved an accuracy of prediction similar to or better

226 than that obtained from many other weather models from other masting plant species (Kelly et al.

227 2013). The cue to masting events is the difference in temperature of the growing seasons one and

228 two years previously. The key weather parameters for white spruce in our region were all some

229 measure of midsummer temperatures, and the resulting model (eq. 4) produced a good fit that

230 was robust in applying to 5 different regions scattered across the southern and central Yukon. We

231 could find no evidence that variation in summer rainfall was associated with variation in cone

232 crops.

233 There were several constraints to this study. The measurement of spruce cone crops was

234 robust, and we pooled all the data from each of the 5 regional locations to produce an average

235 cone crop estimate for each year because there was general synchrony within regions - good

236 cone crop years are generally good across large areas of the boreal forest areas in the Yukon

237 (average $r_{p}$ among all areas $=0.66$, omitting Watson Lake, average $r_{p}=0.81$ ). But we have

238 climate data only for the nearest Environment Canada meteorological station to each region. For 
239 all regions except those at Kluane Lake the meteorological stations are quite close to the field

240 sites. But for Kluane Lake sites (situated about $40 \mathrm{~km}$ from the Burwash Station and Haines

241 Junction Station) it would be more useful to have site-specific weather data to see if predictions

242 could be improved with on-site temperature records. The test of the current model will have to

243 come from better temperature data and further cone counts to determine the model's predictive

244 precision.

245 Our data show that, on average, with the current model one can explain statistically about

$24665 \%$ of the observed variation in the size of the spruce cone crop in a given year. The general

247 belief that large cone crops will reduce ring widths in trees like white spruce has been validated

248 for our Kluane Lake site $(r=-0.48, n=25$ years, $p=0.01)$ but not for our other sites. We do not

249 know what factors might operate to explain the other $35 \%$ of the variation in cone crops in this

250 region. Energy reserves could interact with weather conditions (Pearse et al. 2016), such that hot,

251 dry summers could give rise to mast conditions, but only if the current and preceding cone crops

252 have been poor (Nienstaedt and Zasada, 1990). For white spruce we suggest that part of the 35\%

253 variation in cone crops left to be explained is caused by variation in the effectiveness of wind

254 pollination due to heavy rain or strong winds. It is also possible that short-term, one-off events

255 like a severe wind or frost could affect cone crops and these are at not easy to quantify. In

256 particular if short episodes of frost or heavy rain in spring affect cone crops, it will be almost

257 impossible to recognize this type of effect with current weather data. We assume that when large

258 cone crops are regional in extent, small local storms or frosts are unlikely to explain the

259 variations we have observed.

260 Our objective has been to test the simplest explicit quantitative weather model for the

261 prediction of white spruce cone crops. We did not use the 14 parameter complex model 
Krebs et al.

Page 13

262 suggested by Roland et al. (2014) since it violates the principles of overfitting models outlined in

263 Ginzburg and Jensen (2004). It is possible that the exact quantitative relationships given here

264 may not be general across the boreal forests of northern Canada and Alaska and this requires

265 testing. Cone production in white spruce occurs in nearly absolute synchrony in the Kluane

266 region of the Yukon, reflecting general patterns seen in Picea (Koenig and Knops 1998). High

267 cone crops in a good year like 2014 occur over thousands of square kilometres. There is some

268 variation in cone counts among individual trees in all years (CV among individual trees within

269 sites averages 2.48), but trees that deviate from the general trend in cone numbers are few (2-

$2703 \%)$

271 Being able to predict masting years is useful in a wider ecosystem context than simply

272 recording spruce tree dynamics. Red squirrels, red-backed voles (Myodes rutilus), and a variety

273 of seed-eating birds like crossbills respond dramatically to an abundance of spruce seeds (Krebs

274 et al. 2001). Changing climate may or may not affect masting frequency and result in changes in

275 food chain dynamics. A graphic example of ecosystem impacts of masting can be seen in New

276 Zealand forests (Holland et al. 2015).

277 We suggest that future efforts focus on testing the relationships shown in Figure 2 with

278 further studies in climatically variable areas of northwestern Canada. Our experience is that at

279 least 10 years of data will be required to specify quantitative relationships for other regions and

280 consequently the accumulation of data for testing models can proceed only slowly. Given the

281 pace of climate change in northern Canada (Gauthier et al. 2014), more information on the

282 climatic controls of spruce cone production would provide advance warning of expected

283 changes. High cone crops affect the breeding success of a variety of birds and small mammals 
284 and advance knowledge of their timing would give managers insights into potential effects of

285 climate change on tree regeneration and animal populations.

286 Acknowledgements

287 We thank David Henry, Todd Heakes, many students who counted cones, and Parks Canada

288 staff for assistance in field work. We thank Andrea Byrom for a critical review of the

289 manuscript. Research funding was provided by the Natural Science and Engineering Research

290 Council of Canada (RB, CK), and Environment Yukon. The facilities of the Kluane Lake

291 Research Station of the Arctic Institute of North America were essential to this long-term

292 research program, and we thank Andy and Carole Williams and Lance Goodwin and Sian

293 Williams for their assistance.

294 
Krebs et al.

Page 15

295

296

297

298

299

300

301

302

303

304

305

306

307

308

309

310

311

312

313

314

315

316

\section{References}

Allen, R.B., Hurst, J.M., Portier, J. and Richardson, S.J. 2014. Elevation-dependent responses of tree mast seeding to climate change over 45 years. Ecol. Evol. 4(18): 3525-3537. doi: 10.1002/ece3.1210.

Conway, A.J. and Danby, R.K. 2014. Recent advance of forest-grassland ecotones in southwestern Yukon. Can. J. For. Res. 44(5): 509-520. doi: 10.1139/cjfr-2013-0429.

Fletcher, Q.E. , Landry-Cuerrier, M., Boutin, S., McAdam, A.G., Speakman, J.R., and Humphries, M.M. 2013. Reproductive timing and reliance on hoarded capital resources by lactating red squirrels. Oecologia 173(4): 1203-1215. doi: 10.1007/s00442-013-26993.

Gauthier, S., Bernier, P., Burton, P.J., Edwards, J., Isaac, K., Isabel, N., Jayen, K., Le Goff, H. and Nelson, E.A. 2014. Climate change vulnerability and adaptation in the managed Canadian boreal forest. Environ. Rev. 22(3): 256-285. doi: 10.1139/er-2013-0064.

Ginzburg, L.R., and Jensen, C.X.J. 2004. Rules of thumb for judging ecological theories. Trends Ecol. Evol. 19(3): 121-126. doi:10.1016/j.tree.2003.11.004.

Holland, E.P., James, A., Ruscoe, W.A., Pech, R.P. and Byrom, A.E. 2015. Climate-based models for pulsed resources improve predictability of consumer population dynamics: Outbreaks of house mice in forest ecosystems. PLoS ONE. 10(3): e0119139.

Huber, P.J., and Ronchetti, E.M. 2009. Robust Statistics, 2nd ed. John Wiley and Sons, Holboken, New Jersey. 354 pp.

Juday, G.P., Barber, V., Rupp, S., Zasada, J.C., and Wilmking, M. 2003. A 200-year perspective of climate variability and the response of white spruce in interior Alaska. In Climate 
Variability and Ecosystem Response at Long-term Ecological Research Sites. Edited by D. Greenland, D.G. Goodin, and R.C. Smith. Oxford University Press, Oxford. pp. 226250.

Kelly, D., Geldenhuis, A., James, A., Penelope Holland, E., Plank, M.J., Brockie, R.E., Cowan, P.E., Harper, G.A., Lee, W.G., Maitland, M.J., Mark, A.F., Mills, J.A., Wilson, P.R., and Byrom, A.E. 2013. Of mast and mean: differential-temperature cue makes mast seeding insensitive to climate change. Ecol Lett 16(1): 90-98. doi:10.1111/ele.12020.

Koenig, W.D., Kelly, D., Sork, V.L., Duncan, R.P., Elkinton, J.S., Peltonen, M.S., and Westfall, the evolution of masting behavior. Oikos 102(3): 581-591. doi: 10.1034/j.16000706.2003.12272.x.

332 Krebs, C.J., Boutin, S. and Boonstra, R. 2001. Ecosystem Dynamics of the Boreal Forest: the Kluane Project. Oxford University Press, New York. 511 pp.

334 Krebs, C.J., LaMontagne, J.M., Kenney, A.J., and Boutin, S. 2012. Climatic determinants of white spruce cone crops in the boreal forest of the southwestern Yukon. Botany 90(2): 113-119. doi:10.1139/B11-088.

Kutner, M.H., Nachtsheim, C.J., Neter, J. and Li, W. 2005. Applied Linear Statistical Models, 5th edition. McGraw-Hill/Irwin, Boston. 1396 pp. 
Krebs et al.

Page 17

LaMontagne, J.M., Peters, S., and Boutin, S. 2005. A visual index for estimating cone production for individual white spruce trees. Can. J. Forest Res. 35(12): 3020-3026. doi:10.1139/X05-210

Messaoud, Y., Bergeron, Y., and Asselin, H. 2007. Reproductive potential of balsam fir (Abies balsamea), white spruce (Picea glauca), and black spruce (P. mariana) at the ecotone between mixedwood and coniferous forests in the boreal zone of western Quebec. Amer. J. Bot. 94(5): 746-754. doi:10.3732/ajb.94.5.746.

Nienstaedt, H. and Zasada, J.C. 1990. Picea glauca (Moench) Voss White Spruce. In Silvics of North America, Volume 1, Conifers. Edited by R.M. Burns and B.H. Honkala. Agricultural Handbook 654. United States Department of Agriculture and Forest Service, Washington, DC), pp; 204-226.

Norton, D.A., and Kelly, D. 1988. Mast seeding over 33 years by Dacrydium cupressinum Lamb. (rimu) (Podocarpaceae) in New Zealand: The importance of economies of scale. Functional Ecology 2(3): 399-408. doi: 10.2307/2389413.

Pearse, I.S., Koenig, W.D., and Knops, J.M.H. 2014. Cues versus proximate drivers: testing the mechanism behind masting behavior. Oikos 123(2): 179-184. doi:10.1111/j.16000706.2013.00608.x.

Pearse, I.S., Koenig, W.D., and Kelly, D. 2016. Mechanisms of mast seeding: resources, weather, cues, and selection. New Phytologist. (in press). doi: 10.1111/nph.14114.

Roland, C.A., Schmidt, J.H., and Johnstone, J.F. 2014. Climate sensitivity of reproduction in a mast-seeding boreal conifer across its distributional range from lowland to treeline forests. Oecologia 174(3): 665-677. doi:10.1007/s00442-013-2821-6. 
$\underline{\text { Krebs et al. }}$

Page 18

361 Vander Kloet, S.P., and Cabilio, P. 1996. Ten year study of the annual variation in berry and 362 seed production in a population of Vaccinium corymbosum L. . Am. Midl. Nat. 135(2):

363 349-356. doi: $10.2307 / 2426718$

364 
$\underline{\text { Krebs et al. }}$

Page 19

365 Table 1. Location of the 5 main Yukon regions at which white spruce cone crops have been measured.

366 Weather data from Environment Canada weather stations in each location. Kluane Lake data are

367 gathered in the area between the Haines Junction weather station and the Burwash Airport

368 weather station. Summer is June through August. Data are averages from 1981 to 2010.

\begin{tabular}{|l|l|c|c|c|c|}
\hline Site & $\begin{array}{l}\text { Location of } \\
\text { Meteorological } \\
\text { Station }\end{array}$ & $\begin{array}{c}\text { Mean } \\
\text { summer } \\
\text { temperature } \\
\left({ }^{\circ} \mathrm{C}\right)\end{array}$ & $\begin{array}{c}\text { Total } \\
\text { summer } \\
\text { precipitation } \\
(\mathrm{mm})\end{array}$ & $\begin{array}{c}\text { Mean } \\
\text { annual } \\
\text { temperature } \\
\left({ }^{\circ} \mathrm{C}\right)\end{array}$ & $\begin{array}{c}\text { Mean Total } \\
\text { Annual } \\
\text { precipitation } \\
(\mathrm{mm})\end{array}$ \\
\hline $\begin{array}{l}\text { Haines } \\
\text { Junction }\end{array}$ & $\begin{array}{l}60.7528^{\circ} \mathrm{N}, \\
137.5067^{\circ} \mathrm{W}\end{array}$ & 11.83 & 111.4 & -2.1 & 340.2 \\
\hline $\begin{array}{l}\text { Burwash } \\
\text { Airport }\end{array}$ & $\begin{array}{l}61.3706^{\circ} \mathrm{N}, \\
139.0400^{\circ} \mathrm{W}\end{array}$ & 11.70 & 158.9 & -3.2 & 274.7 \\
\hline Mayo & $\begin{array}{l}63.5931^{\circ} \mathrm{N}, \\
135.8956^{\circ} \mathrm{W}\end{array}$ & 14.57 & 133.8 & -2.4 & 313.5 \\
\hline Faro & $\begin{array}{l}62.2331^{\circ} \mathrm{N}, \\
133.3331^{\circ} \mathrm{W}\end{array}$ & 13.53 & 141.0 & -2.0 & 319.7 \\
\hline Whitehorse & $\begin{array}{l}60.7167^{\circ} \mathrm{N}, \\
135.0500^{\circ} \mathrm{W}\end{array}$ & 13.07 & 106.3 & -0.1 & 262.3 \\
\hline Watson Lake & $\begin{array}{l}60.1167^{\circ} \mathrm{N}, \\
128.8000^{\circ} \mathrm{W}\end{array}$ & 13.83 & 162.0 & -2.4 & 416.4 \\
\hline
\end{tabular}


$\underline{\text { Krebs et al. }}$

Page 20

371 Table 2. Sample sizes for each year for white spruce cone counts for each of the 5 Yukon

372 regions.

\begin{tabular}{|c|c|c|c|c|c|}
\hline & \multicolumn{5}{|c|}{ Number of spruce trees counted for cones } \\
\hline Year & Kluane Lake & Mayo & Farc & Whitehorse & Watson Lake \\
\hline 1986 & 172 & - & - & - & - \\
\hline 1987 & 916 & - & - & - & - \\
\hline 1988 & 700 & - & - & - & - \\
\hline 1989 & 697 & - & - & - & - \\
\hline 1990 & 834 & - & - & - & - \\
\hline 1991 & 553 & - & - & - & - \\
\hline 1992 & 539 & - & - & - & - \\
\hline 1993 & 553 & - & - & - & - \\
\hline 1994 & 560 & - & - & - & - \\
\hline 1995 & 559 & - & - & - & - \\
\hline 1996 & 377 & - & - & - & - \\
\hline 1997 & 333 & - & - & - & - \\
\hline 1998 & 257 & - & - & - & \\
\hline 1999 & 336 & - & - & - & \\
\hline 2000 & 818 & - & - & - & \\
\hline 2001 & 1097 & - & - & - & \\
\hline 2002 & 1139 & - & - & - & - \\
\hline 2003 & 1149 & - & - & - & - \\
\hline 2004 & 1073 & - & - & - & - \\
\hline 2005 & 1089 & 125 & 0 & 65 & 85 \\
\hline 2006 & 1087 & 125 & 0 & 0 & 84 \\
\hline 2007 & 955 & 125 & 93 & 93 & 85 \\
\hline 2008 & 460 & 125 & 96 & 100 & 80 \\
\hline 2009 & 564 & 125 & 96 & 100 & 80 \\
\hline 2010 & 649 & 125 & 96 & 99 & 84 \\
\hline 2011 & 553 & 125 & 96 & 99 & 84 \\
\hline 2012 & 520 & 125 & 96 & 100 & 85 \\
\hline 2013 & 496 & 125 & 95 & 100 & 83 \\
\hline 2014 & 489 & 125 & 96 & 100 & 85 \\
\hline 2015 & 495 & 125 & 96 & 100 & 85 \\
\hline
\end{tabular}


Krebs et al.

Page 21

374 Table 3. Pearson correlations between climate variables related to spruce cone counts. All $\Delta$ variables are the difference of year ( $\mathrm{t}-1)$

375 minus year $(\mathrm{t}-2)$ for that variable. Sample size is 71 region-years.

\begin{tabular}{|c|c|c|c|c|c|c|c|c|c|}
\hline & $\begin{array}{l}\text { Total } \\
\text { Cones }\end{array}$ & $\begin{array}{l}\text { Square- } \\
\text { root total } \\
\text { cones }\end{array}$ & $\begin{array}{l}\text { Log-10 } \\
\text { total } \\
\text { cones }\end{array}$ & $\begin{array}{l}\text { July mean } \\
\text { temperature of } \\
\mathrm{t}-1 \text { year }\end{array}$ & $\begin{array}{l}\text { July mean } \\
\text { temperature } \\
\text { of t-2 year }\end{array}$ & $\Delta \mathrm{T}$ July & $\begin{array}{l}\Delta \mathrm{T} 4 \text { highest } \\
\text { July } \\
\text { temperatures }\end{array}$ & $\begin{array}{l}\Delta \text { June } \\
\text { degree } \\
\text { days }>5^{\circ} \mathrm{C}\end{array}$ & $\begin{array}{l}\Delta \text { July } \\
\text { degree days } \\
>5^{\circ} \mathrm{C}\end{array}$ \\
\hline Total cones & 1.000 & 0.945 & 0.639 & 0.223 & -0.455 & 0.585 & 0.653 & 0.433 & 0.651 \\
\hline Square root total cones & & 1.000 & 0.828 & 0.247 & -0.493 & 0.635 & 0.728 & 0.496 & 0.696 \\
\hline Log-10 total cones & & & 1.000 & 0.217 & -0.504 & 0.620 & 0.694 & 0.503 & 0.645 \\
\hline $\begin{array}{l}\text { July mean temperature } \\
\text { of } \mathrm{t}-1 \text { year }\end{array}$ & & & & 1.000 & 0.314 & 0.557 & 0.321 & 0.551 & 0.557 \\
\hline $\begin{array}{l}\text { July mean temperature } \\
\text { of } \mathrm{t}-2 \text { year }\end{array}$ & & & & & 1.000 & -0.613 & -0.545 & -0.300 & -0.575 \\
\hline$\Delta \mathrm{T}$ July & & & & & $\sqrt{1-3}=3$ & 1.000 & 0.752 & 0.705 & 0.949 \\
\hline $\begin{array}{l}\Delta \mathrm{T} 4 \text { highest July } \\
\text { temperatures }\end{array}$ & & & & & 8 & & 1.000 & 0.392 & 0.714 \\
\hline $\begin{array}{l}\Delta \text { June degree days }> \\
5^{\circ} \mathrm{C}\end{array}$ & & & & & & & & 1.000 & 0.725 \\
\hline $\begin{array}{l}\Delta \text { July degree days }> \\
5^{\circ} \mathrm{C}\end{array}$ & & & & & & & & & 1.000 \\
\hline
\end{tabular}


Table 4. AIC $\mathrm{C}_{\mathrm{c}}$ evaluation of 6 possible regressions of weather variables as predictors of white spruce cone crops.

\begin{tabular}{|c|c|c|c|c|c|c|c|c|}
\hline Model & $\begin{array}{l}\text { Error sum } \\
\text { of squares }\end{array}$ & $\begin{array}{l}\text { No. } \\
\text { observations }\end{array}$ & $\begin{array}{l}\text { No. } \\
\text { variables }\end{array}$ & $\begin{array}{l}\text { Log } \\
\text { likelihood }\end{array}$ & $\mathrm{AIC}_{\mathrm{c}}$ & $\Delta \mathrm{AIC}_{\mathrm{c}}$ & $\begin{array}{l}\text { Evidence } \\
\text { ratio* }\end{array}$ & $\mathrm{R}^{2}$ \\
\hline $\begin{array}{l}\text { Sqrt (cones) predicted by } \Delta \text { degree- } \\
\text { days July and } \Delta 4 \text { maximum } \\
\text { temperatures in July (eq. } 4 \text { ) }\end{array}$ & 3644.113 & 67 & 4 & -133.872 & 276.39 & 0.00 & 1.00 & 0.65 \\
\hline $\begin{array}{l}\text { Sqrt (cones) predicted by } \Delta \text { degree- } \\
\text { days July, } \Delta \text { T July, and } \Delta 4 \text { maximum } \\
\text { temperatures in July (eq. } 5 \text { ) }\end{array}$ & 3630.225 & 67 & 5 & -133.744 & 278.47 & 2.08 & 2.83 & 0.65 \\
\hline $\begin{array}{l}\text { Sqrt (cones) predicted by } \Delta \mathrm{T} \text { July and } \\
\Delta 4 \text { maximum temperatures in July } \\
\text { (eq. } 6 \text { ) }\end{array}$ & 3616.283 & 68 & 4 & -135.106 & 278.85 & 2.46 & 3.42 & 0.64 \\
\hline $\begin{array}{l}\text { Sqrt (cones) predicted by } \Delta 4 \\
\text { maximum July temp., July mean temp. } \\
\text { in year (t-1) and July mean temp. in } \\
\text { year (t-2) (eq. } 7 \text { ) }\end{array}$ & 3621.906 & 68 & 5 & -135.1584 & 281.28 & 4.90 & 11.56 & 0.64 \\
\hline $\begin{array}{l}\text { Sqrt (cones) predicted by mean } \\
\text { temperature in July ( } \mathrm{t}-1) \text {, mean } \\
\text { temperature in July (t-2), and May } \\
\text { rainfall ( } \mathrm{t}-2) \text { from Krebs et al. (2012) }\end{array}$ & 5131.033 & 72 & 5 & -153.590 & 318.09 & 41.70 & $>1000$ & 0.53 \\
\hline Sqrt (cones) predicted by $\Delta \mathrm{T}$ July (eq. & 5679.689 & 72 & 3 & -157.247 & 320.85 & 44.46 & $>2000$ & 0.49 \\
\hline
\end{tabular}




\section{8)}

380

* The evidence ratio gives the likelihood that the current statistical model is as good as the best of the existing models. For example,

381 an evidence ratio of 2.83 means that the best model is more than twice as likely to be better than the current model, given the current 382 data. 


\section{Figure Captions}

Figure 1. Location of the 5 major sites at which spruce cones were counted. Table 1 provides the average climatic variables for each site.

Figure 2. Observed white spruce cone crops for 5 Yukon regions in relation to the predicted cone crop estimated from equation (4), the best multiple regression. $\left(R^{2}=0.65, n=67\right)$. All data plotted on a square root scale.

Figure 3. Relationship between observed square-root transformed white spruce cone counts per tree and observed $\Delta \mathrm{T}$ measured as the mean of the 4 maximum temperatures in July. All data from all regions, $n=66$, Spearman's $r=0.78$. This is the best single variable correlation in our data set.

Figure 4. Relationship between observed square-root transformed white spruce cone counts per tree and $\Delta$ degree-days $>5 \mathrm{C}$ in July, one of the two key variables specified in equation (2). All data from all regions, $n=68$, Spearman's $r=0.67$. This is the second best single variable in our data set. 
Krebs et al.

Page 25

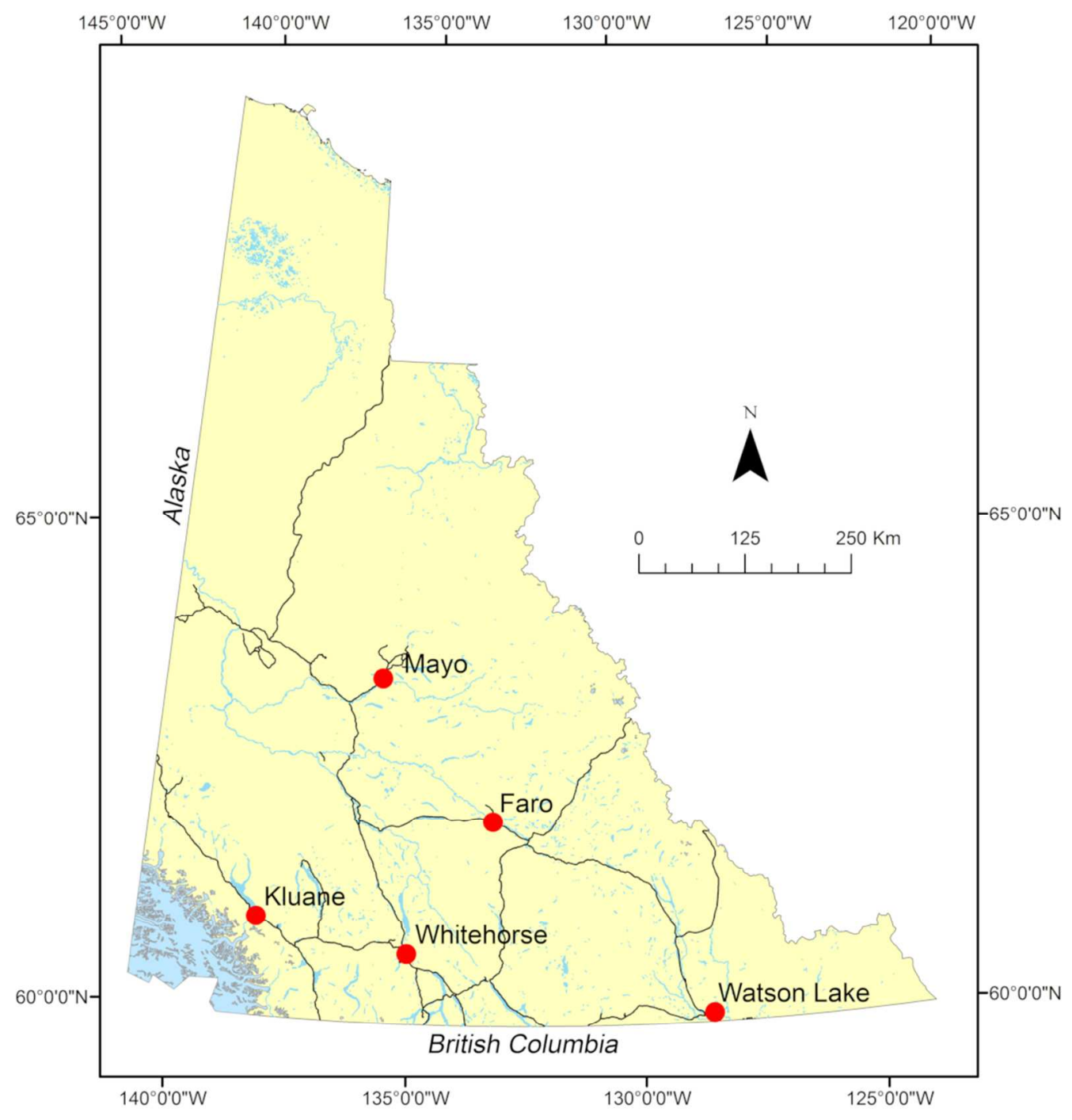

https://mc06.manuscriptcentral.com/cjfr-pubs 
Figure 1. Location of the 5 major sites in the Yukon at which spruce cones were counted. Table 1 provides the average climatic variables for each site. 


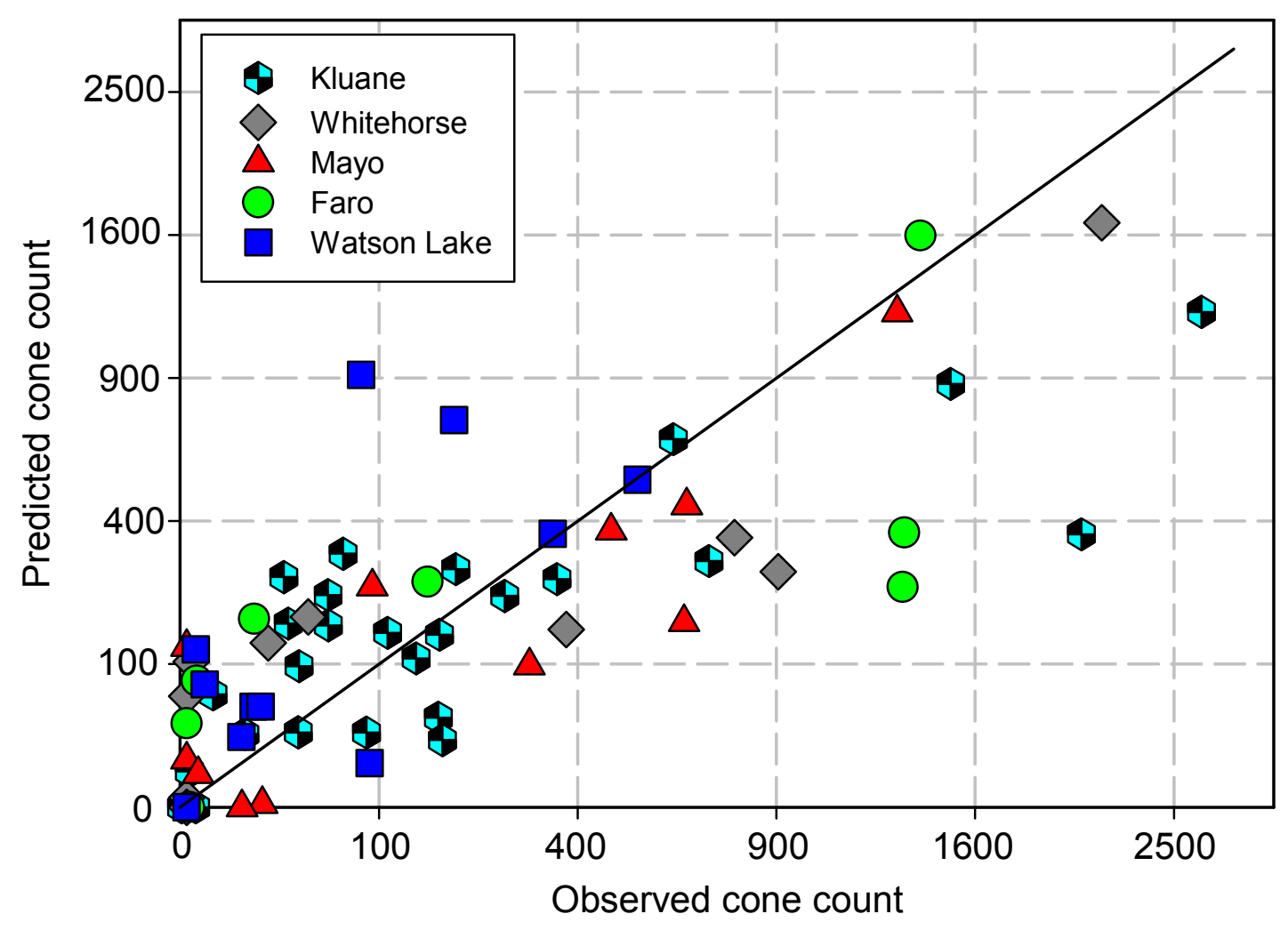


Figure 2. Observed white spruce cone crop (cones per tree) for 5 Yukon regions in relation to the predicted cone crop estimated from equation (4), the best multiple regression. $\left(R^{2}=0.65, n=67\right)$. All data plotted on a square root scale. Line indicates data expected when observed $\mathrm{X}=$ predicted $\mathrm{Y}$. 


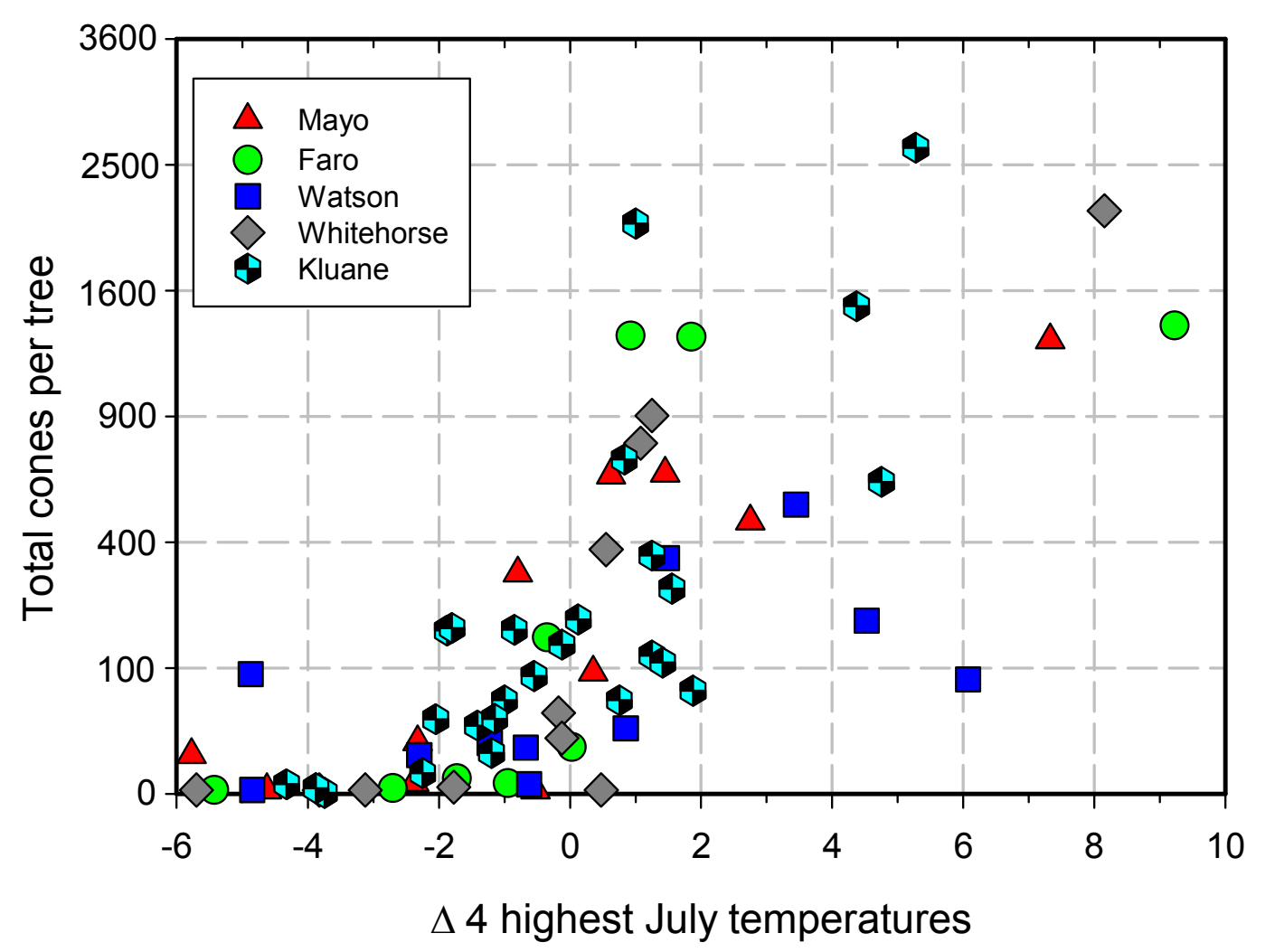

Figure 3. Relationship between observed square-root transformed white spruce cone counts per tree and observed $\Delta \mathrm{T}$ measured as the mean of the 4 maximum temperatures in July. All data from all regions, $n=66$, Spearman's $r=0.78$. This is the best single variable 
correlation in our data set. The correlation shown here is not improved by truncating the data below the $-2^{\circ} \mathrm{C}$ threshold. Cone counts plotted on a square root scale. 


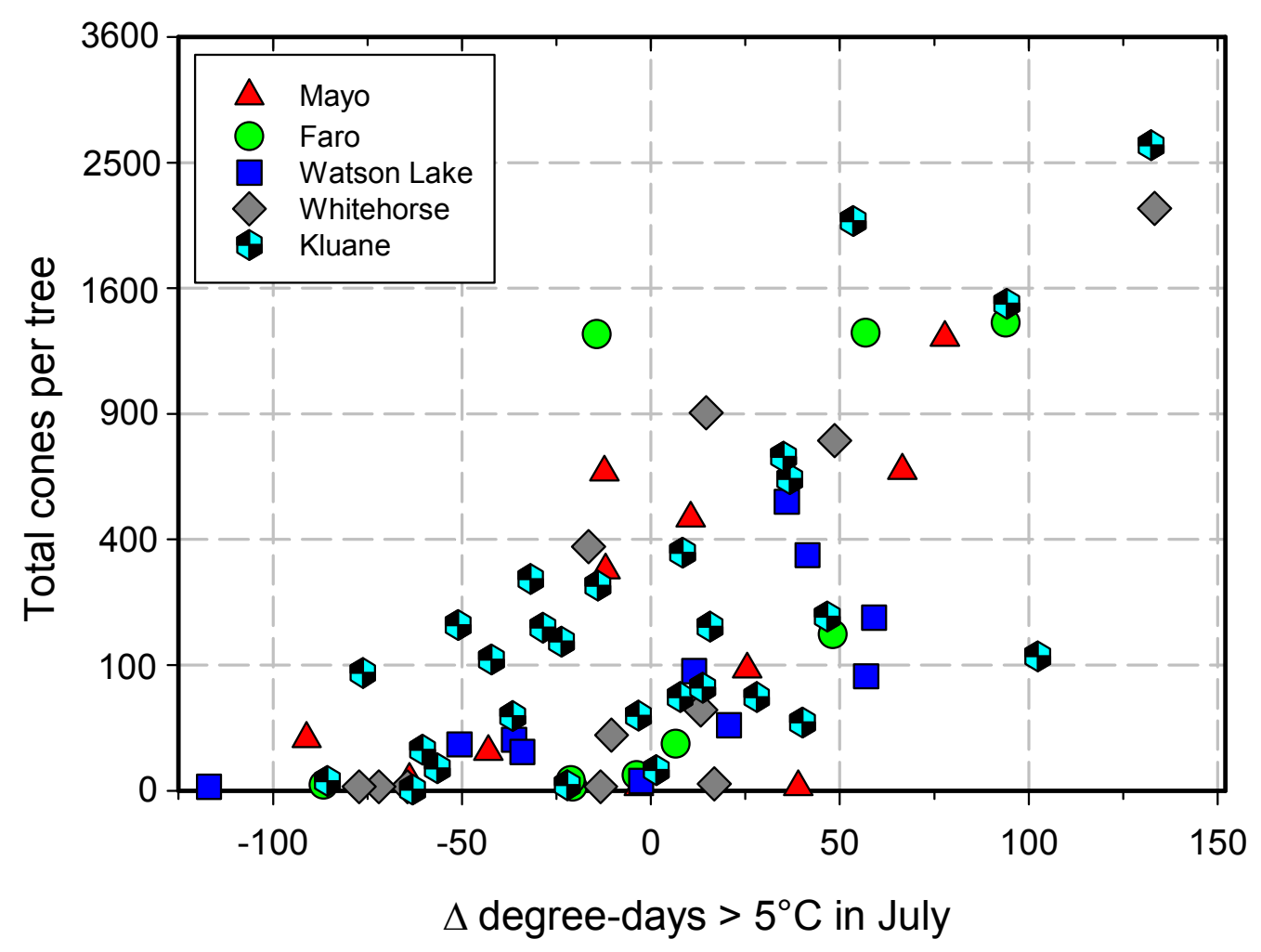

Figure 4. Relationship between observed square-root transformed white spruce cone counts per tree and $\Delta$ degree-days $>5 \mathrm{C}$ in July, one of the two key variables specified in equation (2). All data from all regions, $n=68$, Spearman's $r=0.67$. This is the second best single variable in our data set. 